\title{
POLICY ANALYSIS PP No. 55/2007 IN THE MANAGEMENT OF RELIGIOUS EDUCATION
}

\section{ANALISIS KEBIJAKAN PP No. 55/ 2007 DALAM PENGELOLAAN PENDIDIKAN AGAMA}

\author{
Faridatun Nikmah $^{1}$, Devi Pramitha ${ }^{2}$, Fantika Febry Puspitasari ${ }^{3}$ \\ 1,2,3 UIN Maulana Malik Ibrahim Malang \\ email:fa.rida151289@gmail.com \\ email: devipramitha@uin-malang.ac.id \\ email: fantika@mpi.uin-malang.ac.id
}

Received: 30/01/2020, Accepted: 25/08/2020, Published: 29/08/2020

\begin{abstract}
Implementation of religious education as an education that instills moral values and spiritual until now still raises problematic situations in the community. This is because religious education, especially Islamic education in schools in its implementation, still shows less social issues, such as at least an hour PAI subjects in school are only two hours of lessons a week and the appearance dilemma in the management of religious education. Although substantially religious education was included in the national education system, its management remains handled by the Ministry of Religion. This is under Government Regulation No. 55 of 2007 on Religious Education and Religious Education, which mandates that religious education is the responsibility of the Ministry of Religious.
\end{abstract}

Keywords: PP No. 55/2007, the management of religious education.

\section{ABSTRAK}

Implementasi pendidikan agama sebagai pendidikan yang menanamkan nilai-nilai moral dan spiritual sampai saat ini masih memunculkan situasi problematik di masyarakat. Hal ini dikarenakan pendidikan agama terutama Pendidikan Agama Islam (PAI) di sekolah dalam pelaksanaannya masih menunjukkan berbagai permasalahan yang kurang menyenangkan, seperti sedikitnya jam mata pelajaran PAI di sekolah yang hanya 3 jam pelajaran dalam seminggu dan munculnya dilematik dalam pengelolaan pendidikan keagamaan. Meskipun secara substansial pendidikan keagamaan masuk dalam bagian sistem pendidikan nasional, tetapi dalam pengelolaannya tetap ditangani oleh Kementrian Agama. Hal tersebut sesuai dengan Peraturan Pemerintah Nomor 55 tahun 2007 tentang Pendidikan Agama dan Pendidikan Keagamaan yang mengamanatkan bahwa pendidikan Agama merupakan tanggungjawab Kementerian Agama.

Kata kunci: PP Nomor 55/2007, pengelolaan pendidikan agama. 


\section{A. PENDAHULUAN}

Menurut Undang-Undang Republik Indonesia Nomor 20 tahun 2003 Pasal 3 tentang Sistem Pendidikan Nasional bahwa pendidikan nasional bertujuam untuk mengembangkan potensi peserta didik agar menjadi manusia yang beriman, bertakwa kepada Tuhan Yang Maha Esa, berakhlak mulia, sehat, berilmu, cakap, kreatif, mandiri dan menjadi warga Negara yang demokratis dan bertanggungjawab. Untuk mencapai tujuan tersebut, maka salah satu bidang studi yang harus dipelajari oleh peserta didik di sekolah adalah Pendidikan Agama Islam (PAI). Hal tersebut dimaksudkan agar peserta didik bisa menjadi manusia yang beriman dan bertakwa kepada Allah S.W.T. serta berakhlak mulia. Namun implementasi pendidikan agama sebagai pendidikan yang menanamkan nilai-nilai moral dan spiritual sampai saat ini masih memunculkan situasi problematik di masyarakat. Hal ini dikarenakan pendidikan agama terutama Pendidikan Agama Islam di sekolah dalam pelaksanaannya masih menunjukkan berbagai permasalahan yang kurang menyenangkan, seperti sedikitnya jam mata pelajaran PAI di sekolah yang hanya 2 jam pelajaran dalam seminggu dan munculnya dilematik dalam pengelolaan pendidikan keagamaan.

Meskipun secara substansial pendidikan keagamaan masuk dalam bagian sistem pendidikan nasional, tetapi dalam pengelolaannya tetap ditangani oleh Kementrian Agama. Hal tersebut sesuai dengan Peraturan Pemerintah Nomor 55 Tahun 2007 tentang Pendidikan Agama dan Pendidikan Keagamaan yang mengamanatkan bahwa pendidikan agama merupakan tanggungjawab Kementerian Agama sebagaimana yang dinyatakan pada Pasal 3 ayat (1) bahwa setiap satuan pendidikan pada semua jalur, jenis dan jenjang pendidikan wajib menyelenggarakan pendidikan agama, dan ayat (2) bahwa pengelolaan pendidikan agama dilaksanakan oleh Menteri Agama. Padahal sejatinya Undang-Undang Nomor 20 Tahun 2003 tentang Sistem Pendidikan Nasional bisa menjadi angin segar bagi pendidikan keagamaan, karena sebagaimana ditegaskan dalam Pasal 4 ayat (1) bahwa pendidikan diselenggarakan secara demokratis dan tidak diskriminatif.

Memperhatikan realitas yang dihadapi satuan pendidikan keagamaan hari ini dapat dikatakan bahwa masih tetap terjadi diskriminasi dalam penyelenggaraan pendidikan antara 
pendidikan umum dengan pendidikan agama. Sehingga terkadang bisa saja terdapat kesenjangan kebijakan antara Kementrian Pendidikan Dasar dan Menengah dengan Kementrian Agama. Oleh karena itu, makalah ini akan mengkaji kebijakan PP No. 55 tahun 2007 tentang pendidikan agama dan pendidikan keagamaan.

\section{Kebijakan Pp No. 55 Tahun 2007}

Diterbitkannya PP No. 55 Tahun 2007, tidak lepas dari perjalanan panjang keberpihakan kebijakan pemerintah dari masa ke masa. Jika kita lihat jauh ke belakang, UU SISDIKNAS No. 2 Tahun 1989, memposisikan pendidikan keagamaan sebagai pendidikan luar sekolah (PLS) sama dengan pendidikan umum, pendidikan jabatan kerja, pendidikan kedinasan dan pendidikan kejuruan. Lebih rinci penjabaran tentang pendidikan luar sekolah tersebut tertuang dalam PP No. 73 tahun 1991. Konsekuensi logis dari kebijakan itu adalah jelas menjadikan lembaga pendidikan keagamaan tidak mendapat perlakuan sama dari pemerintah, terutama dalam hal-hal untuk mendapatkan anggaran.

Namun ternyata kondisi tersebut berubah seiring disahkannya UndangUndang SISDIKNAS No. 20 tahun 2003, pada pasal 15 disebutkan bahwa jenis pendidikan mencakup pendidikan umum, kejuruan, akademik, profesi, vokasi, keagamaan dan khusus. Lebih lanjut isi Pasal 12 ayat (4), Pasal 30 ayat (5), dan Pasal 37 ayat (3), juga mengamanatkan perlunya menetapkan Peraturan Pemerintah tentang Pendidikan Agama dan Pendidikan Keagamaan. Sehingga mengingat pentingnya penjabaran lebih rinci serta untuk mempermudah pelaksanaan secara teknis di lapangan, maka pada tanggal 5 Oktober 2007 produk hukum yang berupa Peraturan Pemerintah (PP) Nomor 55 Tahun 2007, ditetapkan oleh pemerintah yang dalam pengelolaannya (sesuai dengan PP No. 55 Tahun 2007 Pasal 9 ayat 3), dilakukan oleh Menteri Agama.

Pada penghujung Tahun 2007, Presiden Susilo Bambang Yudhoyono menetapkan PP No. 55 Tahun 2007 tentang Pendidikan Agama dan Pendidikan Keagamaan. Namun perlu kita ingat bahwa dalam UU SISDIKNAS No. 20 Tahun 2003 tentang Sistem Pendidikan Nasional dikatakan bahwa pendidikan keagamaan adalah bagian integral sistem pendidikan nasional. Seharusnya Undang-Undang ini bisa menjadi tonggak penting politik pendidikan yang bisa menghapus diskriminasi antara pengelolaan sekolah negeri dan swasta serta antara sekolah umum dan sekolah keagamaan, bahkan dalam alokasi anggaran pun menurut 
Pasal 12 harus adil antara sekolah negeri dan swasta.

Pengelolaan pendidikan agama dan keagamaan sebagaimana termaktub dalam PP No. 55 Tahun 2007 Pasal 3 ayat 2 yaitu pengelolaan dilaksanakan oleh menteri agama. Sedangkan dalam penyelenggaraannya pendidikan keagamaan dilakukan oleh pemerintah, pemerintah daerah dan/ atau masyarakat. Adapun pengelolaan pendidikan ini dilakukan untuk menjamin akses masyarakat atas pelayanan pendidikan yang mencukupi, merata, dan terjangkau, mutu dan daya saing pendidikan serta relevansinya dengan kebutuhan dan/ atau kondisi masyarakat dan efektivitas, efisiensi, dan akuntabilitas pengelolaan pendidikan. Adapun standar pengelolaan pendidikan sebagaimana diatur permendiknas Nomor 19 Tahun 2007 memuat enam hal pokok yaitu: (1) perencanaan program; (2) pelaksanaan rencana kerja; (3) pengawasan dan evaluasi; (4) kepemimpinan sekolah atau madrasah; (5) sistem informasi menejemen; dan (6) penelitian khusus.

\section{B. PEMBAHASAN}

\section{Teori Terkait Pp No. 55 Tahun 2007}

Secara dikannya yang bersifat sekuler, keadaan pendidikan di Indonesia berjalan secara dualistis. Pendidikan kolonial yang tidak memperhatikan nilainilai agama dengan pola Baratnya berjalan sendiri, sementara pendidikan Islam yang diwakili pesantren dengan tidak memperhatikan pengetahuan umum juga berjalan sendiri. Secara kultural, pendidikan pada umumnya berada dalam lingkup peran, fungsi dan tujuan yang tidak berada. Semuanya dalam upaya untuk menegakkan martabat manusia melalui transmisi yang dimilikinya. Dunia pendidikan Islam dengan pendidikan pada umumnya, kadangkadang memang mempunyai persamaan dan kadang-kadang juga memiliki perbedaan. Persamaan akan timbul karena sama-sama berangkat dari dua arah pendidikan yakni dari diri manusia yang memang fitrahnya untuk melakukan proses pendidikan, kemudian dari budaya yakni masyarakat yang memang menginginkan usaha warisan nilai, maka semua memerlukan pendidikan (Hasbullah, 2009: 149).

Pendidikan Agama adalah pendidikan yang memberikan pengetahuan dan membentuk sikap, kepribadian, dan keterampilan peserta didik dalam mengamalkan ajaran agamanya, yang dilaksanakan sekuang-kurangnya melalui mata pelajaran/ kuliah pada semua jalur, jenjang dan jenis pendidikan. Sehingga pendidikan agama dapat didefinisikan sebagai upaya 
untuk mengaktualkan

sifat-sifat

kesempurnaan yang telah dianugerahkan oleh Allah S.W.T. kepada manusia, upaya tersebut dilaksanakan tanpa pamrih apapun kecuali untuk semata-mata beribadah kepada Allah (Bawani, 1993: 65). Sedangkan pendidikan keagamaan adalah pendidikan yang mempersiapkan peserta didik untuk dapat menjalankan peranan yang menuntut penguasaan pengetahuan tentang ajaran agama dan/ atau menjadi ahli ilmu agama dan mengamalkan ajaran agamanya.

Dalam peraturan pemerintah RI telah dijelaskan mengenai pengertian tentang pendidikan keagamaan yaitu "pendidikan keagamaan adalah pendidikan yang mempersiapkan peserta didik untuk dapat menjalankan peranan yang menuntut penguasaan pengetahuan tentang ajaran agama dan/ atau menjadi ahli ilmu agama dan mengamalkan ajaran agamanya”. Pendidikan Keagamaan dalam hal ini bermuara dalam konsep pendidikan Islam adalah memberi pendidikan manusia seutuhnya, akal dan hatinya, rohani dan jasmaninya, akhlak dan keterampilannya. Karena itu, pendidikan agama Islam menyiapkan manusia untuk hidup baik dalam keadaan damai maupun perang, dan menyiapkannya untuk menghadapi masyarakat dengan segala kebaikan dan kejahatannya, manis dan pahitnya (AlQardhawi, 1980: 157).
Pendidikan

keagamaan pada

prakteknya lebih bersifat teladan atau peragaan hidup secara riil sehingga peserta didik dapat belajar dengan cara meniru-niru, menyesuaikan dan mengintegrasikan diri dalam suatu suasana. Karena itu, latihan-latihan keagamaan dan pembiasaan itulah yang harus lebih ditonjolkan, misalnya latihan ibadah shalat, berdo'a sebelum belajar, membaca Al-Qur'an, menghafal ayat atau surat-surat pendek, shalat berjamaah di masjid dan mushalla, pembiasaan akhlak dan budi pekerti baik, berpuasa dan sebagainya (Muhaimin, 2010: 294). Kandungan yang mendalam dalam melaksanakan pendidikan keagamaan adalah agar seseorang beriman dan beribadah sesuai dengan agama Islam. Pendidikan keagamaan pada tahap akhir adalah sebuah proses pencapaian yang membentuk kepribadian seseorang setelah melalui tahap mengetahui, berbuat dan mengamalkannya (Daulay, 2009: 35). Kepribadian keagamaan yang dimaksudkan adalah kepribadian yang sesuai dengan ajaran agama Islam secara sempurna.

Negara Indonesia adalah negara yang berdasarkan Ketuhanan Yang Maha Esa merupakan sebuah nilai yang tidak bisa dielakkan. Setiap elemen warga negara wajib mengimplimentasikan perilaku, aturan, dan termasuk juga pendidikan 
yang didasarkan pada Ketuhan Yang Maha Esa. Dengan kata lain, semua yang bersangkut paut pada dunia pendidikan dimuarakan pada satu dasar utama yaitu Ketuhanan Yang Maha Esa. Baru kemudian diturunkan ke dasar-dasar yang lain. Untuk cara pelaksanaannya lebih rinci tergantung pada masing-masing bentuk pendidikan.

Hal tersebut sesuai dengan pembahasan halaman sebelumnya, yaitu tentang UUD 1945 amandemen ke-4 Pasal 31 ayat 3. Serta menurut amanat UU Sisdiknas No. 20 Tahun 2003 bahwa "Pendidikan nasional berfungsi mengembangkan kemampuan dan membentuk watak serta peradaban bangsa yang bermartabat dalam rangka mencerdaskan kehidupan bangsa, bertujuan untuk berkembangnya potensi peserta didik agar menjadi manusia yang beriman dan bertakwa kepada Tuhan Yang Maha Esa, berakhlak mulia, sehat, berilmu, cakap, kreatif, mandiri, dan menjadi warga negara yang demokratis serta bertanggung jawab."

Lebih rinci berdasarkan Peraturan Pemerintah Republik Indonesia No. 55 Tahun 2007 tentang Pendidikan Agama dan Keagamaan disebutkan, bahwa tujuan penyelenggaraan pendidikan pesantren adalah untuk menanamkan keimanan dan ketakwaan kepada Allah S.W.T., akhlak mulia, serta tradisi pesantren untuk mengembangkan kemampuan, pengetahuan, dan keterampilan peserta didik untuk menjadi ahli ilmu agama Islam seta menjadi muslim yang memiliki keterampilan atau keahlianan sebagai penunjang pembangunan kehidupan yang Islami di masyarakat (Fathoni, 2005: 153).

Dari pemaparan di atas menurut penulis ada beberapa implikasi yang harus dilaksanakan oleh seluruh elemen bangsa, yaitu: (1) Tidak ada pandang bulu atau pengecualian bahwa semua jalur, jenjang, dan jenis pendidikan harus bermuatan nilai-nilai "ketuhanan." Dan (2) Pendidikan "berketuhanan" lebih diutamakan, baru kemudian pendidikan ilmu lain. Dapat disimpulkan, dari tiga bentuk pendidikan dalam pembahasan ini maka tujuan pendidikan Islamnya tidak serta merta secara detail harus disamakan. Harus diadakan assessment outcome, yaitu menelaah terlebih dahulu tolak ukur "kesuksesan" seperti apa yang ingin dicapai atau diutamakan. Hal itu sekaligus dikaitkan dengan pengetahuan pendidik tentang sejauh mana kemampuan peserta didik. Misalnya, tolak ukurnya adalah bisa mengerjakan sholat dhuha secara rutin, bisa membaca bacaan sholat dengan benar, membaca kitab kuning, bisa memimpin tahlilan, atau bisa menghafal ayat Al-Qur'an dan sebagainya. Oleh karena itu, setiap 
lembaga

pendidikan

harus

memperhatikan hasil pendidikan Islam yang berupa produk, out put, dan out come seperti apa yang ingin dicapai.

\section{Analisis Kritis Kebijakan Pp No. 55 Tahun 2007}

Dari hasil kajian kebijakan PP No.

55 Tahun 2007 serta didukung oleh kajian teori terkait, maka ada beberapa hal yang perlu diperhatikan, yaitu:

a. Pengelolaan kurikulum pendidikan agama dalam PP tersebut dilaksanakan oleh menteri agama seperti yang termaktub pada Bab II Pasal 3 ayat 2 yang berbunyi "pengelolaan pendidikan agama dilaksanakan oleh menteri agama". Dalam PP No. 55 Tahun 2007 pada intinya berkeinginan untuk meningkatkan kualitas agama dan mengamalkan nilainilai agama, akan tetapi dalam tataran praktisnya pengelolaan pendidikan agama dan keagamaan lebih cenderung pada dikotomi ilmu agama dan umum. Bagaimana tidak, jika kita perhatikan saat ini porsi pendidikan agama di sekolah umum hanya dua jam dalam satu minggu. Dari porsi pembagian ini dapat kita lihat bahwa sekolah hanya mempersiapkan peserta didik memenuhi dimensi individu yang dalam hal ini kognitif saja. Namun dimensi agama, sosial, dan moral dianggap tidak penting. Akibatnya setelah menjadi orang yang berhasil individu tersebut akan memiliki kepribadian yang tidak sehat. Misalnya dosen atau guru yang bermoral tidak baik melakukan kekerasan pada peserta didiknya bahkan hingga melakukan pencabulan terhadap siswinya sendiri.

b. Dalam PP No. 55 Tahun 2007 tentang pendidikan agama kita bisa melihat pada Pasal 5 ayat 6 yang menyebutkan "satuan pendidikan dapat menambah muatan pendidikan agama sesuai dengan kebutuhan". Akan tetapi lagi-lagi dalam tataran praktisnya hal ini sangat susah untuk kita temukan. Karena jam muatan lokal di sekolah biasanya tidak diisi dengan pendidikan agama, melainkan diisi dengan mata peajaran bahasa daerah atau yang lainnya. Sekalipun pendidikan agama dilaksanakan pada muatan lokal maka itu hanya 2 jam pelajaran saja. Apakah ini cukup untuk menjadikan peserta didik sesuai dengan tujuan PP tersebut? Jawabannya tentu tidak. Untuk itu 
dikotomi antara pendidikan umum dan pendidikan agama tidak boleh lagi terjadi dalam praktik pengelolaan pendidikan di Indonesia jika kita ingin merealisasikan tujuan pendidikan nasional. Siswa bukan hanya dituntut secara kognitif tetapi juga moral, responsibility terhadap masyarakat serta kedisiplinan dalam hidupnya.

c. Lahirnya PP No 55 Tahun 2007 ini pemakalah melihat adanya kesempatan bagi lembaga pendidikan Islam agar mendapat bantuan sama seperti lembaga pendidikan lain. Hal ini berdasarkan Pasal 12 ayat 1 yang isinya adalah "Pemerintah pusat atau pemerintah daerah memberi bantuan sumber daya pendidikan kepada pendidikan keagamaan". Penjelasan dari pasal ini adalah, "Pemberian bantuan sumber daya pendidikan meliputi pendidik, tenaga kependidikan, dana, serta sarana dan prasarana pendidikan lainnya. Pemberian bantuan disalurkan secara adil kepada seluruh pendidikan keagamaan pada semua jalur, jenjang dan jenis pendidikan yang diselenggarakan oleh pemerintah, pemerintah daerah, dan/ atau masyarakat. Bantuan dana pendidikan menggunakan satuan dan mata anggaran yang berlaku pada jenis pendidikan lain sesuai peraturan perundang-undangan" Pada pendidikan Diniyah dan Pondok Pesantren yang diatur dalam PP No. 55 Tahun 2007, dengan memberikan penambahanpenambahan kompetensi serta lulus dari ujian nasional, maka lulusan lembaga-lembaga pendidikan memliki hak yang sama dengan lulusan sekolah formal. Adapun efek samping dari PP tersebut bagi pendidikan keagamaan adalah ketimpangan antara pemenuhan kewajiban dan eksekusi kewenangan pemerintah serta birokratisasi dan intervensi kurikulum pesantren/ madrasah diniyah.

d. Kehadiran PP No. 55 Tahun 2007 tentang pendidikan agama dan pendidikan keagamaan diarahkan untuk memperkuat pelaksanaan pendidikan agama dan keagamaan di lembaga pendidikan manapun. Regulasi ini menegaskan perlunya pendidikan yang memberikan pengetahuan dan pembentukan sikap, kepribadian, keterampilan peserta didik dalam mengamalkan ajaran agamanya dan pentingnya 
pendidikan keagamaan dalam mempersiapkan peserta didik memiliki pengetahuan agama dan menjadi ahli ilmu agama dan mengamalkan agamanya. Oleh karena itu regulasi ini memerlukan Peraturan Menteri Agama yang dapat memperjelas maksud PP ini. Regulasi yang akan dikeluarkan akan lebih baik apabila tetap memelihara karakter pendidikan agama tersebut sehingga regulasi yang akan dibuat tetap menjamin otonomi kelembagaan, pengelolaan akademik yang terkait dengan sistem pembelajarannya.

Pendidikan agama disekolah sudah diatur sejak tahun UU No. 4 Tahun 1950, kemudian UU No. 12 Tahun 1954 hingga saat UU No. 20 Tahun 2003, akan tetapi sering kali persoalan hak bergama bagi anak berbenturan dengan persoalan sarak. Dalam kerangka Perlindungan dan pemenuhan hak anak, semua pihak dituntut lebih arief dalam menyikapi problem tersebut jangan sampai persoalan hak beragama bagi anak dibenturkan dengan persoalan sarak. KPAI berkepentingan agar semua anak mendapatkan hak agamanya.

Seperti diungkap diatas walaupun pendidikan agama telah diatur dalam berbagai bentuk regulasi termasuk dalam
UU No. 20 Tahun 2003 dan PP No. 55

Tahun 2007, tapi dalam prakteknya masih sering terjadi pelanggaran. Problem yang belakangan mengemuka, ada satuan pendidikan agama tertentu yang berani pasang bandan dan menolak untuk memeberikan ajaran agama bagi siswa yang tidak seagama dengan lembaga penyelenggara pendidikan berbasis agama tersebut. Perlu disadari bahwa problem agama dalam satuan pendidikan sejatinya merupakan isu lama, sejak sebelum UU Sisdiknas dan hampir menimpa semua agama termasuk pendidikan Katolik dan Kristen.

Dalam konteks problem isu agama di satuan pendidikan, ada dua (2) katagori lembaga satuan pendidikan. Satuan pendidikan tertutup (menerima siswa seagama) dan satuan pendidikan terbuka (meneriama siswa dari berbagai macam agama). Satuan Pendidikan terbuka, terikat oleh UU No. 20 Tahun 2003 dan PP No. 55 Tahun 2007 Pasal 7, mereka wajib memberikan agama sesuai dengan agama siswanya, dengan argumentasi sekolah terbuka membuka layanan publik. Sekalipun Sekolah Dasar Islam Terpadu (SDIT) /MTs/MA, jika kemudian mendeklarasikan sebagai sekolah terbuka dan kemudian ada siswa non muslim (sesuai UU /Peraturan Pemerintah), maka dia wajib menyediakan dan memberikan hak 
beragama bagi siswa yang berbdeda agama tersebut. Sebagai contoh kasus salah satuan pendidikan di Blitar (Katolik), dimana 70\% siswanya muslim, akan tetapi mereka tidak mau menyediakan guru agama Islam. Jika merunut terhadap UU No. 20 Tahun 2003 dan PP No. 55 Tahun 2007, hal tersebut jelas sebuah pelanggaran apapun argumentasinya.

Hal lain yang perlu menjadi perhatian adalah pertama, penyajian pelajaran agama masih formalistik-ritual. Oleh banyak ahli pelajaran agama di Indonesia meragukan efek positifnya. Pelajaran agama masih sering disajikan secara formalisti-ritual belaka, tanpa usaha membangun sikap-sikap keterbukaan dan tanggung-jawab etis. Lebih memprihantinkan lagi, adanya keluhan bahwa banyak guru agama yang memiliki paradigma eksklusif, berpikiran sempit dan tertutup. kedua, kekurangan atau tidak tersedianya tenaga pengajar agama. Di satu pihak pemerintah dengan regulasi-regulasi yang ada, 'mewajibkan' setiap siswa mengikuti pelajaran agama sesuai dengan agamanya. Namun kenyataan bahwa banyak siswa yang menerima pelajaran agama tidak sesuai dengan agamanya, disebabkan tidak tersedianya guru agama (ataupun guru agama yang kompeten). Tidak jarang guru mata pelajaran lain mengajar pelajaran agama. Tentunya ini baik juga, namun tidak ideal. Masih banyak juga guru agama yang tidak memiliki kapasitas dan kompetensi mengampuh mata pelajaran agama.

Program-program pemerintah untuk penyediaan tenaga pengajar agama dan peningkatan kualitas pengajar agama (dengan program sertifikasi dan pelatihan-pelatihan) belum menjangkau seluruh guru. ketiga, fasilitas pelajaran agama yang kurang/tidak representatif. Kenyataan di lapangan pelajaran agama yang tidak ada sekolah-sekolah negeri, khususnya siswa yang jumlahnya lebih sedikit sering tidak mendapatkan tempat/ruang dan jadual yang representatif untuk pelajaran agama.

\section{Alternatif Pemecahan}

Adanya situasi problematik atas munculnya PP No. 55 Tahun 2007 ini mau tidak mau membuat kita juga harus berfikir bagaimana alternative pemecahan masalah-masalah yang timbul. Oleh karena itu untuk penyelesaian masalah mendasar tentu harus dilakukan secara fundamental. Penyelesaian itu hanya dapat diwujudkan dengan melakukan perombakan secara menyeluruh yang diawali dari perubahan paradigma pendidikan sekular menjadi paradigma pendidikan Islam. Hal ini sangat penting dan utama. Artinya, setelah masalah mendasar diselesaikan, barulah berbagai 
macam masalah cabang pendidikan dapat diselesaikan (yang antara lain dikelompokan menjadi masalah aksesibilitas pendidikan, relevansi pendidikan, pengelolaan dan efisiensi, hingga kualitas pendidikan).

Solusi masalah mendasar tersebut adalah dengan melakukan pendekatan sistemik yaitu secara bersamaan dan menyeluruh agar sistem pendidikan dapat berubah lebih baik maka harus pula dilakukan perubahan terhadap paradigma dalam penyelenggaraan sistem ekonomi yang kapitalistik menjadi Islami, tatanan sosial yang permisif dan hedonis menjadi Islami, tatanan politik yang oportunistik menjadi Islami, dan ideologi kapitalismesekuler menjadi mabda Islam, sehingga perubahan sistem pendidikan yang materialistik pun dapat diubah menjadi pendidikan yang dilandasi oleh aqidah dan syariah Islam sesuai dengan karakteristiknya. Perbaikan semacam ini pun perlu dikokohkan dengan aspek formal, yaitu dengan dibuatnya regulasi tentang pendidikan yang berbasiskan pada konsep nilai-nilai Islam. Salah satu bentuk nyata dari solusi mendasar itu adalah dengan mengubah UU Sistem Pendidikan yang ada dan menggantinya dengan UU Sistem Pendidikan Islam. Hal paling mendasar yang wajib diubah tentunya adalah asas sistem pendidikan. Sebab asas sistem pendidikan itulah yang menentukan hal-hal paling prinsipil dalam sistem pendidikan, seperti tujuan pendidikan dan struktur kurikulum.

Kemudian solusi untuk permasalahan yang bersifat Derivat (Turunan) dalam hal ini secara garis besar terdapat dua solusi, yaitu: Pertama, solusi sistemik. Yakni solusi dengan mengubah sistemsistem sosial yang berkaitan dengan sistem pendidikan, antara lain: sistem ekonomi, sistem politik, sistem sosial, ideologi, dan lainnya. Penerapan ekonomi syari'ah sebagai pengganti ekonomi kapitalis ataupun sosialis akan menyeleraskan paradigma pemerintah dan masyarakat tentang penyelenggaraan pendidikan, dimana pendidikan sebagai salah satu kewajiban negara yang harus diberikan kepada rakyatnya dengan tanpa adanya pembebanan biaya yang memberatkan ataupun diskriminasi terhadap masyarakat yang tidak memiliki sumber dana (capital) untuk mengenyam pendidikan, karena pendanaan pendidikan harus dialokasikan dari kas negara, bukan dibebankan kepada rakyat sepenuhnya.

Kedua, solusi teknis. Yakni solusi untuk menyelesaikan berbagai permasalahan internal dalam penyelenggaraan sistem pendidikan. Di antaranya, secara tegas, pemerintah harus mempunyai komitmen untuk mengalokasikan dana pendidikan 
nasional dalam jumlah yang memadai untuk pengelolaan pendidikan agama. Merekrut jumlah tenaga pendidik dan kependidikan sesuai kebutuhan di lapangan disertai dengan adanya peningkatan kualitas dan kompetensi yang tinggi, serta jaminan kesejahteraan dan penghargaan untuk mereka. Pembangunan sarana dan prasarana yang layak dan berkualitas untuk menunjang proses belajar-mengajar. Penyusunan kurikulum yang berlandaskan pada nilainilai Islam (Al-Qur'an dan Hadits).

\section{KESIMPULAN}

Kebijakan pemerintah melalui Indang-Undang Nomor 20 Tahun 2003 tetang Sistem Pendidikan Nasional bertekad menghilangkan diskriminasi pendidikan. Namun untuk penyelenggaraan satuan pendidikan agama dan keagamaan pemerintah mengaturnya dengan PP No. 50 Tahun 2007. Tuntutan UU dalam hal pengelolaan satuan pendidikan, merupakan beban berat bagi satuan pendidikan keagamaan Islam yang memiliki sumber daya sangat terbatas, apalagi pengelolaannya diserahkan kepada Kementrian Agama. Disini terlihat adanya diskrimasi dalam pengelolaan pendidikan.

Sejatinya problematikan yang dihadapi oleh satuan pendidikan keagamaan Islam antara lain: pertama, pembiayaan dalam penyelenggaraan pendidikan sangat minim; kedua, tenaga pendidik dan kependidikan belum memenuhi standar kompetensi; ketiga, sarana dan prasaran yang masih memprihatinkan; keempat, waktu pelaksanaan pendidikan agama di sekolah sangat terbatas. Dari pembahasan di atas setidaknya penulis dapat memberikan rekomendasi sebagai berikut:

1. Pola pembelajaran pendidikan agama perlu dikembangkan secara sistematis dan terukur agar anak tidak hanya mengetahui dan memahami ajaran agama tetapi juga melekat dalam kepribadian setiap manusia.

2. Perlu memperkuat sinergisitas antara Kementerian Agama dan Kementerian pendidikan dan Kebudayaan dalam hal pengembangan pendidikan agama.

3. Dalam rangka pemenuhan hak anak, Kementerian Agama dan Kementerian Pendidikan harus bertindak tegas kepada satuan pendidikan yang jelas melangar UU N0. 20 Tahun 2003 dan PP No. 55 Tahun 2007. 


\section{DAFTAR PUSTAKA}

Al-Qardhawi, M.Y. (1980). Pendidikan Islam dan Madrasah Hasan AlBanna. Jakarta: Bulan Bintang.

Depdiknas. (2003). UU No. 20 tahun 2003 tentang SISDIKNAS. Jakarta: Dirjen Pendidikan Dasar dan Menengah.

Daulay, H.P. (2009). Pemberdayaan Pendidikan Islam di Indonesia. Jakarta: PT Rineka Cipta.

Fathoni, M.K. (2005). Pendidikan Islam dan Pendidikan Nasiona Paradigma Baru. Jakarta: Depag RI Dirjend Kelembagaan Agama Islam.
Hasbullah. (2009). Dasar-dasar Ilmu Pendidikan. Jakarta: Rajawali Pers.

Muhaimin, et.al. (2009). Strategi Belajar-Mengajar Penerapannya dalam Pembelajaran Pendidikan Agama.

Peraturan Pemerintah Republik Indonesia Nomor 55 Tahun 2007 tentang Pendidikan Agama dan Pendidikan Keagamaan.

(2008). Undang-Undang Nomor 20

Tahun 2003. Bandung: Citra Umbara. 
